International Journal of Biology, Pharmacy and Allied Sciences (IJBPAS) 'A Bridge Betueen Caboratory and QRando'

\author{
WwW.ijbpas.com
}

ANTIOXIDANTS AS A TARGET IN CHRONIC OBSTRUCTIVE PULMONARY DISEASE - A REVIEW

\title{
BAKSHI $\mathrm{S}^{1}$, DAS MK ${ }^{2}$, DEBHUTI $\mathrm{P}^{3}$, GHOSH $\mathrm{S}^{4}$ AND DASGUPTA $\mathrm{S}^{5 *}$
}

1: Department of Pharmacy, NSHM Knowledge Campus, Kolkata group of Institutions, 124, B.L. Saha Road, Kolkata-700053, India, (ORCID:0000 00015230 4995)

2: Indquench Lifescience Innovations (OPC) Private Limited, Plot - 31/761, Dasbatia, Tamando, PS Tamando, Bhubaneswar, Khordha, Orissa- 751028, India, (ORCID-0000-0002-8691-7201)

3: Assistant Professor, Department of Pharmacy, NSHM Knowledge Campus, Kolkata group of Institutions, 124, B.L. Saha Road, Kolkata-700053, India

4: Assistant Professor, Department of Pharmacy, NSHM Knowledge Campus, Kolkata group of Institutions, 124, B.L. Saha Road, Kolkata-700053, India

5: Faculty, Department of Pharmaceutical Science and Technology, Maulana Abul Kalam Azad University of Technology, Haringhata, Nadia, 741249, India, (https://orcid.org/0000-0002-0256$848 \mathrm{X})$

*Corresponding Author: Dr. Sandipan Dasgupta: E Mail: sandi.dj02@gmail.com; Phone No. 91-8777598058

Received 27 $7^{\text {th }}$ Dec. 2020; Revised $29^{\text {th }}$ Jan. 2021; Accepted $15^{\text {th }}$ Feb. 2021; Available online $1^{\text {st }}$ Oct. 2021 https://doi.org/10.31032/IJBPAS/2021/10.10.5686

\begin{abstract}
Chronic obstructive pulmonary disease (COPD) is composed of emphysema, chronic bronchitis, and small airway obstruction caused by environmental exposures, primarily cigarette smoking. About 1520 percent of smokers develop COPD, so it is assumed that many host factors interact with the environment, which increases the risk of developing this disease in many patients. The major pathogenic factors that cause the disease include infection, inflammation, protease, and antiprotease imbalance that increase antioxidant defenses. The oxidant-antioxidant imbalance is recognized as one of the significant factors in COPD pathogenesis. Oxidants from cigarette smoke are the leading cause of ROS that can suppress cytokine production, including TNF- $\alpha$ and interleukins, via the NF-kB pathway inhibition that triggers COPD. In non-smokers, the antioxidant level is high, which reduces the risk of developing COPD than smokers who have a high oxidant level. There are multiple causes
\end{abstract}


of COPD, so a multi-target therapeutic approach is necessary. In this review, we discuss the mechanism of antioxidants in COPD and the latest development.

\section{Keywords: COPD, oxidants, antioxidants, ROS}

\section{INTRODUCTION}

A chronic obstructive pulmonary disease is characterized by airflow limitation combined with emphysema and chronic bronchitis [1]. The airflow limitation is associated with an abnormal inflammatory response of the lungs. The pathophysiology of COPD involves recurrent oxidative stress, i.e., oxidant/antioxidant imbalance, protease/antiprotease imbalance, caused mainly due to inhalation of oxidants from the environment [2]. Cigarette smoke serves as the major risk factor for developing COPD and is also the major source of reactive oxygen species (ROS). Increased level or prolonged exposure to ROS may lead to the pathological modification of nucleic acids, proteins, carbohydrates, or lipids, leading to changes in cellular metabolism and, finally, apoptosis. Tobacco smoke contains many free radicals such as superoxide $(\mathrm{O} 2 \cdot-)$ and hydroxyl $(\cdot \mathrm{OH})$ radicals in a very high concentration. Upon entering the lungs, the cigarette smoke first gets exposed to epithelial lining fluid(ELF), which covers airway epithelial cells (AECs). The most crucial antioxidant in ELF of the normal human lower respiratory tract is catalase. Besides, it also contains superoxide dismutase (SOD), glutathione reductase, peroxidase, and ceruloplasmin. After crossing the ELF barrier, the ROS reach AEC's plasma cell membranes, further worsening the disease prognosis. Alpha-1 antitrypsin deficiency leads to pulmonary emphysema and COPD [3]. The antioxidants can treat it. Vitamin A, E, C has antioxidative properties that can be useful in the treatment and prophylaxis of this disease in many patients. Chronic obstructive pulmonary disease patients exhale more hydrogen peroxide and lipid peroxidation products than normal people. This oxidative stress develops COPD. Nacetylcysteine, a mucolytic drug and an antioxidant with glutathione peroxidase, may decompose $\mathrm{H}_{2} \mathrm{O}_{2}$ and lipid peroxides [4]. In a clinical trial study with vitamin $\mathrm{C}$ on subjects having COPD, it is seen that the prevalence of COPD in heavy smokers with the lowest quartile Q1 $<48.50 \mathrm{mg}$ and lowmiddle quartile $\mathrm{Q} 2=48.50-84.38 \mathrm{mg}$ of vitamin $\mathrm{C}$ intake was higher than the subjects who took high-middle quartile $\mathrm{Q} 3=84.38-141.63 \mathrm{mg}$ and highest quartile Q4 >141.63 $\mathrm{mg}$ of vitamin $\mathrm{C}$ intake. A reduction of $76.7 \%$ risk in COPD was observed with a Q3 vitamin compared to Q1 vitamin C intake in heavy smokers [5]. 


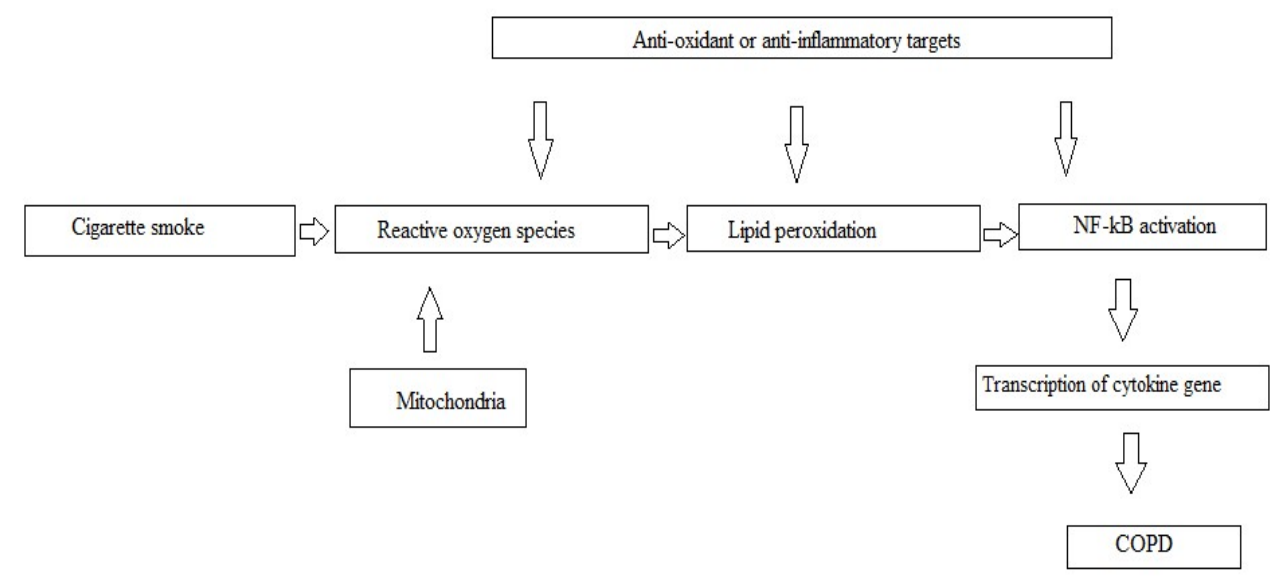

\section{OXIDATIVE STRESS-}

Oxidative stress is the prime of COPD. Cigarette smoke has many oxidants that affect the lungs; some electrons from the mitochondrial electron transport chain also take part in oxidative stress, and alpha antitrypsin deficiency can lead to oxidative stress due to an increasing amount of oxidant levels. In this review, the objective is to know about the mechanism of oxidants and antioxidants in COPD, the latest research work done on antioxidants to show some effects on COPD, and the role of dietary and supplementary antioxidants in the treatment.

\subsection{Cigarette smoke-}

Smoking produces an imbalance in the normal levels of oxidants and antioxidants to impact oxidative stress both in the lungs and systemically. Oxidants included in cigarette smoke can directly injure cells and tissues by inactivating defense mechanisms, which further initiates inflammation, which elevates oxidative stress [6].
The smoke from the cigarette contains a stable semiquinone in a quantity that reduces oxygen to produce superoxide, a direct precursor of hydrogen peroxide. The reactive oxidant substances generated by smoking induce inflammation in the lung and its airway [7]. Smokers inhale $1 \mu \mathrm{g}$ of iron per 25 cigarettes, and the smoke itself releases iron from ferritin and provides ample iron to the lung surface fluid to generate the toxic hydroxyl radical through the Haber Weiss and Fenton reactions. Studies have shown an increase in lavage concentrations of iron and ferritin, serum ferritin levels, and nonheme iron concentrations in the lung and liver tissue in rats exposed to cigarette smoke. Lavage ascorbate concentrations were also decreased, leading to oxidative stress. After removing the particles by filtering the cigarette smoke, most of these changes were altered [8]. Vitamin E protects the lungs in smokers and non-smokers and is a good antioxidant in response to smoke- 
induced oxidative stress [9]. Oxides of nitrogen present in cigarette smoke react with superoxide to form reactive peroxynitrite [10]. Cigarette smoke also oxidizes alpha-1 antitrypsin and damages the DNA. Oxidation of alpha-1 antitrypsin reduces its ability to inhibit neutrophil elastase, which destroys the protein elastin on the cell surface, and cells lose elasticity and ultimately leads to emphysema. It also activates macrophages that attract neutrophils and releases high oxidants of superoxide and hydrogen peroxide through the NADPH oxidase complex. Phagocytes obtained from the lungs of healthy smokers release enough oxidants to oxidize and inactivate alpha-1 antitrypsin. Neutrophils also release myeloperoxidase, which converts hydrogen peroxide to hypochlorous acid, a potent oxidant. Thus the oxidants damage the cells and create emphysema and, ultimately, COPD [11].

\subsection{Alpha 1 antitrypsin deficiency-}

Alpha-1 antitrypsin has been shown to inhibit iNOS, nitric oxide release, and NF$\mathrm{KB}$ activation. Increased lung damage in individuals with alpha-1 antitrypsin deficiency is seen. So alpha-1 antitrypsin replacement therapy or other neutrophil elastase inhibitor therapies may decrease oxidative stress and inflammation [12-15].

\subsection{Mitochondrial-Derived ROS and COPD-}

One of the endogenous sources of ROS is mitochondrial respiration. Mitochondrial electron transport chain under normal conditions leak $1-2 \%$ of all electrons as ROS published by Vander Toornet et al [16]. It has been reported that the lipophilic fraction present in cigarette smoke extract is responsible for a decrease in mitochondrial membrane potential, ATP production, and concomitant generation of mitochondrial ROS. Some cytokines increase the production of mitochondrialderived ROS. ASMCs from COPD patients, when subjected to inflammatory stress from IL-1, IFN $\gamma$, and $\mathrm{TNF} \alpha$, produce larger amounts of mitochondrial-derived ROS [17]. Mitochondrial derived ROS can drive MMP-2 activation, resulting in a negative feedback cycle that degrades mitochondrial membrane potential and impairs mitochondrial function [18]. Activated MMP2 and MMP-9 can enter into the mitochondria and damage their structure and integrity. This phenomenon leads to the release of cytochrome $\mathrm{c}$ and activates apoptosis [19]. As an effect of mitochondrial damage, ROS levels continue to increase and begin to damage mitochondrial DNA. The damaged mitochondrial DNA continues to dysfunction the electron transport chain that produces a higher amount of ROS. 


\section{Pathogenesis}

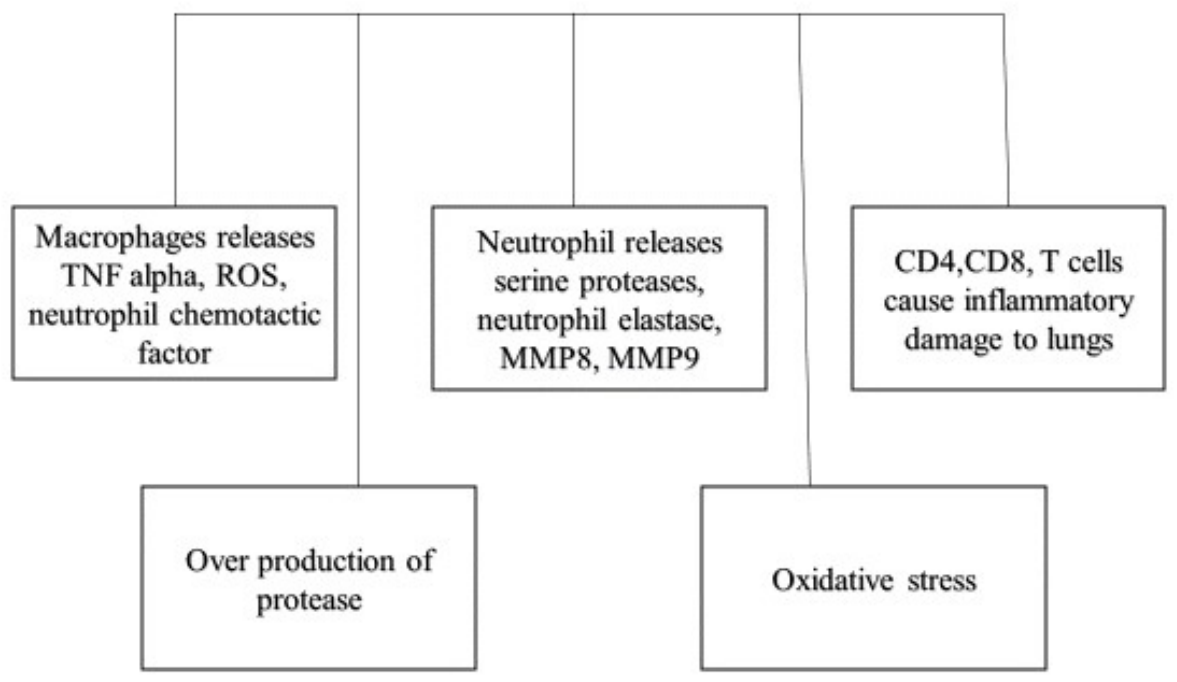

Figure 2: Pathogenesis of COPD

\section{OTHER PATHOGENESIS}

\subsection{Protease- antiprotease imbalance-}

Another cause of emphysema is the imbalance between proteases and antiproteases that results in lung parenchymal destruction. These degradations occur when the level of protease increase than the antiprotease level [20]. These antiproteases are inactivated by the smoke of the cigarette and biomass fire [21]. These smokes trigger an acute pulmonary response, which activates resident alveolar macrophages, resulting in a neutrophil influx into the lungs. These smokes produce many macrophages, neutrophils, and CD8+ T cells in the lungs, causing inflammation. The macrophages and neutrophils release various proteases, including neutrophil elastase, that destroys the protective flexible protein in the lungs. The proteins destroyed are elastin, proteinase 3, matrix metalloproteinases
(MMPs), and cathepsins in a large amount and surpass the level of antiproteases. The proteases help each other activate themselves or inhibit their endogenous inhibitors, such as neutrophil elastase, which inhibits the tissue inhibitors of MMPs, and MMPs, which degrades $\alpha 1-$ antitrypsin that neutralizes iNOS [22]. These proteinases cleave components of the extracellular matrix, elastin fibers, and collagen, which are essential for the flexibility of the membrane. This cleavage turns the elastin fibers into elastin fragments and also turns collagens into collagen-derived peptides that are prolineglycine-proline. These peptides and fragments are chemotactic for monocytes, which further provoke macrophages and neutrophils at the lungs [23-24]. Hence, this accumulates macrophage and neutrophil into the lungs and causes inflammation, 
leading to apoptosis and, finally, pulmonary cell destruction.

\subsection{Inflammation-}

Cigarette smoking and other inhaled pollutants contain many oxidants that irritate the lungs and activates inflammation, oxidative stress, and protease/antiprotease imbalance.

Bronchoalveolar lavage fluid (BALF) showed increased cytokines, proteases, and other biomarkers [25]. Increased proinflammatory cytokines like TNF- $\alpha$, IL$1 \beta$, and IL-6, are increased in COPD, which causes inflammation. The transcription factor nuclear factor (NF)-kB is activated, which further activates the TNF- $\alpha$ gene that triggers apoptosis, and the cell dies. NF- $\mathrm{BB}$ regulates the expression of genes for proinflammatory mediators involved in the lung infiltration by inflammatory cells such as macrophage and neutrophils. So, it results in oxidative stress and inflammation that causes lung cell destruction and finally leads to emphysema, fibrosis of small airways, altering the lung function. NF- $\mathrm{KB}-$ positive epithelial cells and macrophages increased in smokers and COPD patients [26].

Neutrophils are involved in the immune response that is the source of reactive oxygen metabolites, inflammatory cytokines, and tissue-damaging enzymes [27]. The oxidants in the lungs give rise to the accumulation of the neutrophils at the alveolar site. They are involved in the formation of mucus in chronic bronchitis and the destruction of lung tissue in emphysema. Mucin gene expression has been proposed as the principal factor governing the differentiation of epithelial cells into goblet cells, which produce the mucous. It is observed that neutrophil elastase (NE) and reactive oxygen species increase epithelial mucin mRNA and protein expression in vitro [28-29]. Neutrophil elastase also inhibits MMP inhibitors and helps MMP to function.

Macrophages also release reactive oxygen species, chemotactic factors, inflammatory cytokines, smooth muscle constrictors, mucus gland activators, and extracellular matrix proteins and also attract neutrophils at the inflammation site. These can degrade a similar spectrum of proteins to neutrophil enzymes [30].

$\mathrm{T}$ cells $(\mathrm{CD} 4+$ and $\mathrm{CD} 8+)$ are increased in the alveolar walls that release lytic substances and damage the lung interstitium. Further induces structural cell apoptosis and result in emphysema [31].

\section{ANTIOXIDANT TYPES-}

-Enzymes - Superoxide dismutase, glutathione peroxidase, and catalase.

- Hormones-melatonin.

- Proteins-Albumin, ferritin, etc.

- Small molecules-phenolic compounds, carotenoids, glutathione, tocopherol, vitamins. 


\section{MECHANISM OF ANTIOXIDANTS}

Antioxidants mainly neutralize the oxidants by supplying electrons to them and thus prevent the cells from losing electrons that are necessary for cell function [32].

Antioxidants in COPD show their mechanism by targeting multiple factors. Glutathione is a major antioxidant, so there are antioxidants (e.g., Procysteine) that increase the synthesis of glutathione and also increase efferocytosis. Oxidoreductase enzyme such as thioredoxin donates electrons to help reduce oxidized proteins, ribonucleotides, and cell signaling molecules such as protein kinase, NF-kB and phosphatidylinositol three kinases.
Some also decrease the number of macrophages and neutrophils and reduces inflammation. Nuclear factor erythroid 2related factor $2(\mathrm{Nrf} 2)$ is a transcription factor that degrades proteosomes. Agonists of Nrf2 increase the glutathione synthesis (Figure 3).

\section{COPD TYPES-}

Forced expiratory volume per second (FEV1) indicates the function of the lungs, and the higher the FEV1 better is the pulmonary function and vice-versa. The FVC is a forced vital capacity; the FEV1/FVC ratio is used to calculate the severity of the pulmonary disease (Table 1).

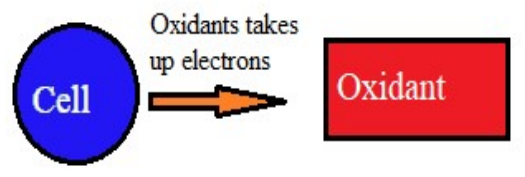

Cells without anti-oxidants

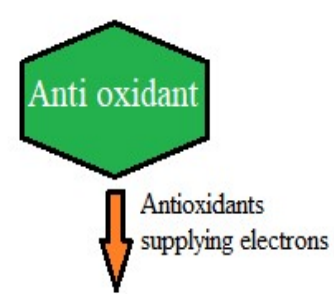

Oxidant

\section{Cell}

Cell is prevented

from losing electrons

Cells with anti-oxidants

Figure 3: Antioxidant mechanism

Table 1: Types of COPD

\begin{tabular}{|c|c|c|}
\hline Stage & COPD & FEV1 \\
\hline 1 & Mild & $\mathbf{8 0 \%}$ \\
\hline 2 & Moderate & $\mathbf{5 0 - 8 0 \%}$ \\
\hline 3 & Severe & $\mathbf{3 0 - 5 0 \%}$ \\
\hline 4 & Very severe & low \\
\hline
\end{tabular}




\section{ANTIOXIDANTS AS TREATMENT-}

Systemic antioxidant capacity and antioxidant vitamins-

The decline in the antioxidant level increases the release of ROS from peripheral blood neutrophils. The depletion of total antioxidant capacity in smokers is associated with decreased levels of major plasma antioxidants in smokers. Decreased vitamin Elevels were reported in leukocytes and BAL fluids in smokers [33-34]. Vitamin $\mathrm{C}$ is a potent antioxidant and can be gained by diet and also available quickly. In vitro studies showed that Cigarette smoke-induced lipid peroxidation of plasma is decreased by ascorbate. Dietary antioxidant supplementation is one of the most straightforward approaches to boost antioxidant defense systems. Supplementation of vitamin C, vitamin E, and $\beta$-carotene in smokers and patients with COPD showed a decrease in the symptoms of COPD [35-38].

\section{Directly increasing lung antioxidant capacity-}

The most direct way to redress the oxidant imbalance in COPD would be to increase the lung's capacity to produce antioxidants, significantly increasing thiol compounds.

\section{Glutathione-}

Several thiol and non-thiol antioxidants show potential interest in COPD.

Several studies have suggested that GSH homeostasis may play a central role in maintaining the integrity of the lung airspace epithelial barrier. When there is a decrease of GSH in the epithelial cell, loss of barrier function and increased permeability is seen. Human studies have shown elevated levels of GSH in epithelial lining fluid in chronic cigarette smokers compared with non-smokers. A direct increase of lung cellular levels of GSH would be a logical approach to enhance the antioxidant potential in the treatment of COPD.

\section{$\mathrm{N}$-acetyl-L-cysteine (NAC)-}

NAC is a pro-drug with an acetyl group linked to the nitrogen atom of cysteine, allowing better stability and absorption of cysteine.NAC has direct and indirect antioxidant properties, which have been extensively assessed in in-vitro and in-vivo studies.26 However, inhalation of NAC requires a compressor, is associated with a foul odor, and can cause bronchospasm. More convenient and safe delivery of NAC is through the oral route. It also modulates inflammatory responses. NAC is also used as a mucolytic agent to reduce mucus viscosity and improve mucociliary clearance [39-40].

\section{N-acystelyn (NAL)-}

NAL, a lysine salt of NAC, is a mucolytic and antioxidant (reducing) thiol compound. The advantage of NAL over NAC is that it has a neutral $\mathrm{pH}$ in a solution, whereas NAC is acidic. NAL can be aerosolized 
into the lung without causing significant side effects. NAL inhibited oxidantmediated interleukin (IL)-8 release in alveolar epithelial A549 cells, suggesting an antiinflammatory effect of NAL. Therefore, NAL may represent an attractive alternative approach to augment the antioxidant screen, thereby inhibiting inflammatory responses in the lungs [41].

\section{N-isobutyrylcysteine (NIC)-}

NIC is a thiol compound, and it does not undergo effective first-pass hydrolysis, so it has higher oral bioavailability. The oral bioavailability can be as high as $80 \%$, depending on food intake. However, when evaluated as a therapy for exacerbations of chronic bronchitis, NIC performed no better than placebo and not as well as NAC [42].

\section{Erdosteine-}

It contains two sulfhydryl groups that get converted to 3 metabolites after first-pass metabolism into three metabolites that have mucoactive and antioxidant properties that can scavenge free radicals. The mucolytic effect of erdosteine is maybe due to the presence of a sulfhydryl group present in it.In the "Equalife" randomized placebocontrolled clinical study, erdosteine was administered orally $300 \mathrm{mg}$ twice daily for eight months [43]. to the patients, and it is seen that those who were receiving erdosteine had fewer exacerbations and spent few days compared to the placebo group.

\section{Procysteine-}

Procysteine (L-2-oxothiazolidine-4carboxylate) is a cysteine-donating compound that increases the cysteine levels of the cells and increases the level of cellular glutathione [44]. This compound can be cytotoxic, and variation in the uptake levels of GSH has been shown in various cellular models [45].

\section{Other antioxidants-}

\section{Superoxide dismutase glutathione peroxidase-}

Salen-metal compounds are superoxide dismutase (SOD) mimetics. Researchers had also demonstrated enhanced antioxidant enzyme activity in alveolar macrophages from hamsters after cigarette smoke exposure, which resulted in reduced mortality when the animals were subsequently exposed to more than $95 \%$ oxygen [46].

\section{Ebselen-}

It is a seleno organic compound. Activity is the same as glutathione peroxidase. Glutathione peroxidase-1 (GPX) is a member of the selenium-dependent protein family that catalyzes the reduction of hydrogen peroxide and prevents cigarette smoke-induced inflammation in murine lungs [47]. So ebselen is an organoselenium molecular mimic of GPX, and it has been shown to protect against 
pulmonary inflammationin several lung inflammation models in mice, including cigarette smoke exposure [48-50]. It increases the efficiency of GSH as an antioxidant and can thus be used as a therapy against oxidative stress and inflammation.

\section{Hydrogen-}

It is a potent antioxidant that reduces hydroxyl radicals and prevents cell damage. Studies have determined that hydrogen-rich water supplementation in SMP30 knockout mice exposed to cigarette smoke prevents the appearance of emphysema [51]. Preclinical studies have been done, but a clinical trial is yet to be done.

Inhibition of superoxide production from inflammatory neutrophils: phosphodiesterase four inhibitor-

These inhibitors act by increasing intracellular concentrations of cAMP, which has a broad range of antiinflammatory effects on various cells involved in asthma and COPD [52]. The increase in cAMP in neutrophils blocks the assembly of NADPH oxidase and thus inhibits superoxide production. These compounds also potently inhibit expression of various cytokines, such as tumor necrosis factor (TNF)- $\alpha$ and monocyte inflammatory protein (MIP)-1 $\beta$, and therefore may have a broad anti inflammatory profile.
Modulation of redox-sensitive transcription factors and inflammatory pathways-

Many inflammatory genes are responsible for COPD. The activation of NF-kBin monocytes/macrophages can trigger the release of proinflammatory mediators in lung epithelial fluid, which activate the neutrophils to the site of the airways and cause inflammation. I- $\kappa \mathrm{B}$ kinase-2 (IKK)mediated phosphorylation of $\mathrm{I}-\kappa \mathrm{B}$ is required for its ubiquitination and degradation; therefore, small molecule inhibitors of this enzyme would be expected to block the nuclear translocation of NF- $\kappa \mathrm{B}$ [53-55].

\section{NADPH oxidase inhibition-}

Celastrol is an electrophilic triterpenoid that has a dual antioxidant mechanism. It is a potent Nrf2 agonist that helps to produce other antioxidants, and it is an NADPH oxidase inhibitor [56-57].

\section{Diet-}

Dietary modification may be another avenue of promising intervention for COPD patients. Consumption of fruits and vegetables can prevent COPD and emphysema. Curcumin has antiinflammatory and antioxidant properties; studies have shown that fruits containing bisphenol or flavonoids are effective antioxidants, for example, blueberry and guava. Vitamin $\mathrm{E}$ and $\mathrm{C}$ are very potent antioxidants. Vitamin $\mathrm{C}$ is effective in improving lung fibrosis. Specially colored 
fruits and vegetables act as antioxidants that neutralize the oxidants and prevent their damage to the cells. Vitamin C, E, A are well known as antioxidants so they must be taken as diet $[\mathbf{5 8}, \mathbf{5 9}, \mathbf{6 0}]$.

\section{Fruits and Vegetables-}

Apples, pears, peppers, guava, curcumin, and green leafy vegetables are found to decrease the risk of COPD due to their antioxidant and anti-inflammatory properties. The COPD patients with a diet rich in fruits and vegetables showed an annual increase in FEV1 compared with the control group who were following a normal diet over. The intake of fresh fruits and vegetables, specially colored, is essential for a healthier lifestyle with no smoking [61-63].

\section{Vitamin and Nonvitamins-}

Fruits and vegetables contain various vitamins, hence act as antioxidants beneficial in COPD or any other diseases where the cause is oxidative stress. Higher intake of vitamin $\mathrm{C}$, a water-soluble antioxidant, was associated with higher levels of FEV1, which indicates an excellent pulmonary function. The fatsoluble antioxidant carotenoids or vitamin A increase in the lung function that has been noted by FEV1/ FVC [64].

\section{Minerals-}

Deficient intake of some minerals is found in COPD patients. Decrease levels of calcium, magnesium, and selenium were found in the serum, and diet is found in underweight patients with severe COPD [65]. Lower in takes of other minerals like calcium and zinc were found in elderly COPD patients than those in non-COPD subjects.

\section{Whole grains and fibers-}

The fiber contains the antioxidant and antiinflammatory properties, which act as a protective measure in the patients. Fiberintake decreases the levels of $\mathrm{C}$ reactive protein in serum and cytokines (IL6 , TNF- $\alpha$ ) and produces a higher level of adiponectin, which has an antiinflammatory property [66].

\section{Vitamin D-}

It is found that vitamin D helps in normal growth and development of the lung and immune responses and decreases COPD progression.

Fish and n-3 Polyunsaturated Fatty Acids-

n-3 PUFAs and fish have anti-inflammatory properties with beneficial effects and clinical applications in several chronic inflammatory diseases.It directly modulates the inflammatory gene expression (adhesion molecules, cytokines, matrixdegrading enzymes, cyclooxygenase-2) via the regulation of nuclear transcription factors, mainly the oxidative stresssensitive pro-inflammatory NF- $\kappa \mathrm{B}$ [67] and prevents the activation of various genes that promote cell apoptosis. 


\section{Caffeine and polyphenols-}

Caffeine is a bronchodilator and has antiinflammatory property and polyphenols have antioxidant and anti-inflammatory properties, so improvement in lung function and reduced mortality from respiratory disease is seen, but in COPD, it may not work. Further studies should be conducted on its effect on COPD.

\section{Alcohol-}

Studies have found that subjects with low alcohol consumption had higher levels of FEV1, which indicates good pulmonary function and a decreased risk of COPD compared to non-consumers $[68,69]$.

Table 2: Antioxidants in the treatment

\begin{tabular}{|c|c|}
\hline Antioxidants & Mechanism \\
\hline Glutathione & Neutralizes oxidants in the lungs[3] \\
\hline NAC & Cysteine donor [39-40] \\
\hline NAL & Cysteine donor [41] \\
\hline NIC & Cysteine donor [42] \\
\hline Erdosteine & Mucolytic [43] \\
\hline Procysteine & Cysteine donor [44,45] \\
\hline SOD & Neutralizes oxidants in alveoli [46] \\
\hline Ebselen & Reduction of hydrogen peroxide [47-50] \\
\hline Hydrogen & Inhibits superoxide [52] \\
\hline Phosphodiesterase4inhibitor (roflumilast) & Produces antioxidants [56,57] \\
\hline NADPH oxidase inhibitor (celastrol) & Neutralizes oxidants [58-60] \\
\hline Diet (Vitamin C,E,A) &
\end{tabular}

Table 3: Summary of the research works upon a few antioxidants by different authors

\begin{tabular}{|c|c|c|c|c|c|c|}
\hline $\begin{array}{l}\text { SL } \\
\text { No. }\end{array}$ & $\begin{array}{l}\text { Author/ } \\
\text { Year }\end{array}$ & Model & Technique used & Findings & $\begin{array}{c}\text { Limitation suggested by } \\
\text { the author }\end{array}$ & $\begin{array}{l}\text { Further work } \\
\text { suggested by } \\
\text { authors }\end{array}$ \\
\hline 1. & $\begin{array}{l}\text { X. Y. LI } \\
\text { et al/ } 1994\end{array}$ & $\begin{array}{l}\text { epithelial } \\
\text { cell line } \\
\quad \text { in } \\
\text { vitro/Rat } \\
\text { model in } \\
\quad \text { vivo }\end{array}$ & $\begin{array}{l}\text { Radiolabeling BSA with } \\
\text { 125lodine, Measurement } \\
\text { of the Permeability of } \\
\text { A549 Epithelial Cells to } \\
\text { 12SI BSA, Isolation of Rat } \\
\text { Type 11 Alveolar } \\
\text { Epithelial Cells, } \\
\text { Intratracheal Instillation } \\
\text { and Bronchoalveolar } \\
\text { Lavage in the Rat, } \\
\text { Measurement of Rat Lung } \\
\text { Epithelial Permeability is } \\
\text { done. }\end{array}$ & $\begin{array}{l}\text { The harmful effect of } \\
\text { WSC on the cell } \\
\text { monolayer was } \\
\text { decreased by GSH in the } \\
\text { culture medium.WSC } \\
\text { and VSC increased lung } \\
\text { epithelial permeability } \\
\text { after intratracheal } \\
\text { instillation in rats, with a } \\
\text { fall in GSH in BAL } \\
\text { fluid.It supports that } \\
\text { cigarette smoke-induced } \\
\text { increase in epithelial } \\
\text { permeability is oxidant- } \\
\text { mediated, and that the } \\
\text { glutathione antioxidant } \\
\text { system has an important } \\
\text { protective role against } \\
\text { this effect of cigarette } \\
\text { smoke. }\end{array}$ & $\begin{array}{c}\text { The combination of } \\
\text { treatment with BSO and } \\
\text { cigarette smoke } \\
\text { condensate in vivo study } \\
\text { did not have an additive } \\
\text { effect. This is difficult to } \\
\text { interpret from the in } \\
\text { vitro A549 epithelial cell } \\
\text { monolayer studies. In } \\
\text { vivo response is } \\
\text { complicated by factors } \\
\text { like the recruitment of } \\
\text { leukocytes to the } \\
\text { airspaces, changes in } \\
\text { other antioxidant defense } \\
\text { systems in alveolar space, } \\
\text { and the failure to induce } \\
\text { low concentrations of } \\
\text { lung GSH comparable } \\
\text { with those obtained in } \\
\text { vitro. [70] }\end{array}$ & $\begin{array}{c}\text { Further work } \\
\text { to overcome } \\
\text { the } \\
\text { limitations } \\
\text { that includes } \\
\text { many factors } \\
\text { should be } \\
\text { done. }\end{array}$ \\
\hline 2. & $\begin{array}{c}\text { Frank } \\
\text { Antonicel } \\
\text { li/2004 }\end{array}$ & $\begin{array}{l}\text { In vitro } \\
\text { cell } \\
\text { culture } \\
\text { and in } \\
\text { vivo rat } \\
\text { model }\end{array}$ & $\begin{array}{c}\text { Bronchoalveolarlavage,En } \\
\text { dotoxin assay, NF-kB } \\
\text { staining is done in animal } \\
\text { study. Isolation of RNA } \\
\text { and reverse } \\
\text { transcription,Analysis of } \\
\text { IL-8 mRNA by } \\
\text { PCR,RNase protection } \\
\text { assay is done in case of cell }\end{array}$ & $\begin{array}{l}\text { Influx of neutrophils into } \\
\text { the lungs cause of LPS is } \\
\text { inhibited by treatment } \\
\text { with the antioxidant } \\
\text { NAL. This in vivo effect, } \\
\text { which correlated with } \\
\text { NF-kB activation from } \\
\text { alveolar leukocytes in } \\
\text { response to LPS, was }\end{array}$ & $\begin{array}{c}\text { LPS stimulation } \\
\text { upregulated TNF- } \alpha \text {, } \\
\text { MIP-1 } \alpha \text { etc cytokines, } \\
\text { NAL couldn't } \\
\text { downregulate all those } \\
\text { cytokines. [71] }\end{array}$ & $\begin{array}{l}\text { Its effect on } \\
\text { other } \\
\text { cytokines } \\
\text { should be } \\
\text { done. }\end{array}$ \\
\hline
\end{tabular}




\begin{tabular}{|c|c|c|c|c|c|c|}
\hline & & & culture study. & $\begin{array}{l}\text { also inhibited by NAL. } \\
\text { NAL decreased } \\
\text { LPSmediated IL-8 } \\
\text { release.TGF- } \beta 1 \text { were } \\
\text { downregulated by a } \\
\text { cotreatment with NAL. }\end{array}$ & & \\
\hline 3. & $\begin{array}{c}\text { Sandra } \\
\text { Hodge } \\
\text { et.al/2011 }\end{array}$ & $\begin{array}{l}\text { Mice } \\
\text { model } \\
\text { and } \\
\text { patients } \\
\text { with } \\
\text { COPD }\end{array}$ & $\begin{array}{c}\text { Flexible bronchoscopy, } \\
\text { Flow cytometric analysis } \\
\text { of human and murine } \\
\text { macrophage } \\
\text { phenotypes,quantification } \\
\text { of cytokines, Investigation } \\
\text { of Human Alveolar } \\
\text { Macrophage Phenotype in } \\
\text { vitro and statistical } \\
\text { analysis } \\
\end{array}$ & $\begin{array}{l}\text { The treatment with } \\
\text { procysteine increased the } \\
\text { level of glutathione that } \\
\text { is a potent antioxidant; it } \\
\text { also increased the } \\
\text { phagocytic activity of } \\
\text { macrophages in both } \\
\text { humans and mice. }\end{array}$ & $\begin{array}{c}\text { Tissue macrophages and } \\
\text { alveolar macrophages are } \\
\text { different in phenotype. } \\
{[72]}\end{array}$ & $\begin{array}{l}\text { Its effect on } \\
\text { different } \\
\text { cytokines } \\
\text { should be } \\
\text { done. }\end{array}$ \\
\hline 4. & $\begin{array}{l}\text { Piero A. } \\
\text { Martoran } \\
\text { a et.al } \\
/ 2005\end{array}$ & $\begin{array}{l}\mathrm{C} 57 \mathrm{Bl} / 6 \mathrm{~J} \\
\text { male mice } \\
\text { model }\end{array}$ & $\begin{array}{l}\text { Acute and chronic studies } \\
\text { were done. For the } \\
\text { determinationofdesmosine, } \\
\text { freshlungswerehomogeniz } \\
\text { ed, processed, and } \\
\text { analyzed by high-pressure } \\
\text { liquid chromatography. } \\
\text { BALF was taken and } \\
\text { various cytokines were } \\
\text { determined. }\end{array}$ & $\begin{array}{c}\text { Roflumilast inhibits } \\
\text { BALF neutrophil influx } \\
\text { and increase IL-10. IL- } \\
10 \text { is capable to prevent } \\
\text { neutrophil influx in the } \\
\text { roflumilast-treated } \\
\text { groups. It inhibits } \\
\text { various cytokines. PDE4 } \\
\text { inhibitor, roflumilast } \\
\text { partially ameliorates } \\
\text { acute and chronic lung } \\
\text { inflammation } \\
\text { andfullypreventsparench } \\
\text { ymaldestructioninduced } \\
\text { bycigarette smoke in } \\
\text { mice. }\end{array}$ & $\begin{array}{c}\text { Oral route } \\
\text { administration is used } \\
\text { here. }[73]\end{array}$ & $\begin{array}{c}\text { Further } \\
\text { research } \\
\text { work should } \\
\text { be done. }\end{array}$ \\
\hline 5. & $\begin{array}{c}\text { Koike, } \\
\text { Ishigami, } \\
\text { Sato, et } \\
\text { al/2014 }\end{array}$ & $\begin{array}{l}\text { SMP30- } \\
\text { KO mice } \\
\text { model }\end{array}$ & $\begin{array}{l}\text { Measurement of Total VC, } \\
\text { Oxidative Stress, and } \\
\text { Protein Concentration is } \\
\text { done. Determination of } \\
\text { Vascular Endothelial } \\
\text { Growth Factor, TNF-a, } \\
\text { and mRNA Transcripts of } \\
\text { Collagen is done. } \\
\text { Evaluation of Apoptosis } \\
\text { and Cell Proliferation in } \\
\text { the Lungs and statistical } \\
\text { analysis is done. }\end{array}$ & $\begin{array}{l}\text { Vitamin C treatment } \\
\text { after cessation of smoke } \\
\text { exposure showed } \\
\text { increased mRNA } \\
\text { transcripts of collagen; } \\
\text { decreased oxidative } \\
\text { stress, inflammation,and } \\
\text { alveolar septal cell } \\
\text { apoptosis; and promoted } \\
\text { cell proliferation and } \\
\text { hence reconstituted the } \\
\text { alveolar maintenance } \\
\text { program in the lungs of } \\
\text { SMP30-KO mice. }\end{array}$ & $\begin{array}{c}\text { No limitation from the } \\
\text { authors [74] }\end{array}$ & $\begin{array}{l}\text { It showed } \\
\text { good } \\
\text { therapeutic } \\
\text { effect so } \\
\text { further } \\
\text { reaearch can } \\
\text { be done. }\end{array}$ \\
\hline
\end{tabular}

\section{DISCUSSION}

Antioxidants play an essential role in neutralizing the free radicals produced by cigarette smoke and endogenous factors. Various cytokines, macrophages, and neutrophils are responsible for the inflammation in the lungs. TNF- $\alpha$, NF-kB genes are also involved in the pathogenesis of COPD. Research articles showed that antioxidants could prevent these inflammations by cytokines, the neutrophil influx, or by inhibiting the genes related to COPD and increasing other antioxidants. Liu Y et al. 2018 found that diallyl disulfide, which is having antioxidative properties, decreases cell influx in BALF and suppresses pro-inflammation cytokine production such as TNF- $\alpha$, interleukin- $1 \beta$, IL-6 and inhibits NF-kB pathway in rat emphysema model induced by cigarette 
smoke extract [75]. Hence, it indicates a promising antioxidative agent in emphysema treatment that is a part of COPD. Koike et al. 2014 showed that vitamin $\mathrm{C}$ treatment after cessation of smoke exposure on the SMP30-KO mice model showed increased mRNA transcripts of collagen, decreased oxidative stress, inflammation, and alveolar septal cell apoptosis and thus reconstituted the alveolar maintenance program in the lungs. Sandra Hodge et al. 2011 showed that the treatment with procysteine increased the level of glutathione and also increased the phagocytic activity in both mice model and COPD patients. Piero A. Martorana et al. 2005 showed roflumilast that is a phosphodiesterase four inhibitor, inhibits BALF neutrophil influx and various cytokines, and it partially ameliorates acute and chronic lung inflammation but fully prevents parenchymal destruction induced by cigarette smoke in $\mathrm{C} 57 \mathrm{Bl} / 6 \mathrm{~J}$ mice. Other researches found that treatment with NAL inhibits the influx of neutrophils that were caused by LPS, and NAL also inhibited NF-kB activation. So antioxidants can prevent the progress of COPD and can be used as a treatment.

\section{CONCLUSION}

The increased level of oxidants produced from cigarette smoke and endogenous factors is the main cause of COPD in patients. The mitochondrial-derived ROS activates MMP 2 and MMP 9, which further damages the mitochondrial membrane as negative feedback. So the ROS should be neutralized or should be prevented from being synthesized to avoid cell damage. The imbalance of oxidants and antioxidants can be repaired by using various chemical compounds. The antioxidants can neutralize free radicals and prevent cell damage. An antioxidant such as thiol molecules, superoxide dismutase, dietary polyphenols and vitamins, antioxidant mimetics, and inhibitors of oxidative stress-induced signaling pathways are capable of treating COPD. Dietary polyphenols, such as resveratrol and curcumin, vitamin $\mathrm{C}, \mathrm{E}, \mathrm{A}$, inhibit NF$\kappa \mathrm{B}$ activation, histone acetylation, and proinflammatory cytokine. Some antioxidants increase the synthesis of other antioxidants and also reduce hydroxylradicals and hydrogen peroxide and protect the cells from getting damaged. They help in the treatment of COPD and regulate inflammatory response at the molecular level. Antioxidants are considered as safest treatment without any side effects. They can be used as a promising treatment in COPD in the future. Some compounds are still ongoing trials and are yet to be established.

\section{ACKNOWLEDGEMENT}

I would like to thank my institute for providing me the facilities for this work. I 
am also thankful to my mentor for guiding me throughout the writing process.

\section{REFERENCES}

[1] Kim V, Criner GJ. Chronic bronchitis and chronic obstructive pulmonary disease. Am J Respir Crit Care Med. 2013.

[2] Fischer BM, Pavlisko E, Voynow JA. Pathogenic triad in COPD: oxidative stress, protease-antiprotease imbalance, and inflammation. Int J Chron Obstruct Pulmon Dis. 2011.

[3]Escribano A, Amor $\mathrm{M}$, Pastor $\mathrm{S}$, et al. Decreased glutathione and low catalase activity contribute to oxidative stress in children with $\quad \alpha-1 \quad$ antitrypsin deficiency. Thorax. 2015; 70(1): 82-83. doi:10.1136/thoraxjnl-2014-205898

[4] Kasielski M, Nowak D. Long-term administration of $\mathrm{N}$-acetylcysteine decreases hydrogen peroxide exhalation in subjects with chronic obstructive pulmonary disease. Respir Med. 2001; 95(6): 448-456. doi:10.1053/rmed.2001.1066

[5] Park HJ, Byun MK, Kim HJ, et al. Dietary vitamin $\mathrm{C}$ intake protects against COPD: the Korea National Health and Nutrition Examination Survey in 2012. Int J Chron Obstruct Pulmon Dis. 2016; 11: 2721-2728. Published 2016 Oct 31. doi:10.2147/COPD.S119448

[6]Church DF, Pryor WA. Free-radical chemistry of cigarette smoke and its toxicological implications. Environ Health Perspect. 1985.

[7]Laniado-Laborín R. Smoking and chronic obstructive pulmonary disease (COPD).
Parallel epidemics of the 21 century. Int $J$ Environ Res Public Health. 2009; 6(1): 209224. doi:10.3390/ijerph6010209

[8] Ghio AJ, Hilborn ED, Stonehuerner JG, et al. Particulate matter in cigarette smoke alters iron homeostasis to produce a biological effect. Am J Respir Crit Care Med. 2008.

[9] Van Antwerpen VL, Theron AJ, Richards GA, et al. Vitamin E, pulmonary functions, and phagocyte-mediated oxidative stress in smokers and non-smokers. Free RadicBiol Med. 1995.

[10] Fischer BM, Voynow JA, Ghio AJ. COPD: balancing oxidants and antioxidants. Int J Chron Obstruct Pulmon Dis. 2015; 10: 261-276. Published 2015 Feb 2. doi:10.2147/COPD.S42414

[11] Félix-Antoine Vézina, MD1 André M. Cantin, MD. Antioxidants and Chronic Obstructive Pulmonary Disease. Journal of the COPD foundation.

[12] Malerba M, Clini E, Cremona G, et al. Exhaled nitric oxide in patients with PIZZ phenotype-related alpha1-anti-trypsin deficiency. Respir Med. 2001.

[13] Chan ED, Pott GB, Silkoff PE, Ralston AH, Bryan CL, Shapiro L. Alpha-1antitrypsin inhibits nitric oxide production. J Leukoc Biol. 2012.

[14] Brantly ML, Nukiwa T, Crystal RG. Molecular basis of alpha-1 antitrypsin deficiency. Am J Med 1988.

[15] Brantly ML, Paul LD, Miller BH, Falk RT, Wu M, Crystal R. Clinical features and hystory of the destructive lung disease associated with a1-anti-trypsin deficiency 
of adults with pulmonary symptoms. Am Rev Respir Dis 1988.

[16] M. van der Toorn, D. Rezayat, H. F. Kauffman et al., "Lipidsoluble components in cigarette smoke induce mitochondrial production of reactive oxygen species in lung epithelial cells," American Journal of Physiology-Lung Cellular and Molecular Physiology. 2009.

[17] P. A. Kirkham and P. J. Barnes, "Oxidative stress in COPD," Chest, vol. 144, no.1, pp.266-273, 2013.

[18] H.-Z. Zhou, X. Ma, M. O. Gray et al., "Transgenic MMP-2 expression induces latent cardiac mitochondrial dysfunction," Biochemical and Biophysical Research Communications, 2007.

[19] J. M. Santos, S. Tewari, J. Y. Lin, and R. A. Kowluru, "Interrelationship between activation of matrix metalloproteinases and mitochondrial dysfunction in the development of diabetic retinopathy," Biochemical and Biophysical Research Communications, vol.438, no.4, pp.760764, 2013.

[20] Churg A, Wright JL. Proteases and emphysema. CurrOpinPulm Med. 2005; 11: 153-159.

[21] Cavarra E, Lucattelli M, Gambelli F, et al. Human SLPI inactivation after cigarette smoke exposure in a new in vivo model of pulmonary oxidative stress. Am J Physiol Lung Cell Mol Physiol. 2001

[22] Shapiro SD. Proteinases in chronic obstructive pulmonary disease. BiochemSoc Trans.
[23] Hunninghake GW, Davidson JM, Rennard $\mathrm{S}$, et al. Elastin fragments attract macrophage precursors to diseased sites in pulmonary emphysema. Science. 1981.

[24] Weathington NM, van Houwelingen AH, Noerager BD, et al. A novel peptide CXCR ligand derived from extracellular matrix degradation during airway inflammation. Nat Med. 2006.

[25] Barnes PJ, Chowdhury B, Kharitonov SA, et al. Pulmonary biomarkers in chronic obstructive pulmonary disease. Am J Respir Crit Care Med. 2006.

[26] DiStefano, A.; Caramori, G.; Oates, T.; Capelli, A.; Lusuardi, M.; Gnemmi, I.; Ioli, F.; Chung, K.F.; Donner, C.F.; Barnes, P.J.; et al. Increased expression of nuclear factor-kappa B in bronchial biopsies from smokers and patients with COPD. Eur. Respir. J. 2002.

[27] Hiemstra PS, van Wetering S, Stolk J. Neutrophil serine proteinases and defensins in chronic obstructive pulmonary disease: effects on pulmonary epithelium. Eur Respir J 1998; 12: 1200-8.

[28] Rogers DF. Airway goblet cells: responsive and adaptable front-line defenders. Eur Respir J 1994; 7: 1690-706.

[29] Takeyama K, Dabbagh K, Jeong Shim J, et al. Oxidative stress causes mucin synthesis via transactivation of epidermal growth factor receptor: role of neutrophils. J Immunol 2000.

[30] Tetley TD. New perspectives on basic mechanisms in lung disease. 6. Proteinase imbalance: its role in lung disease. Thorax 1993. 
[31] Majo J, Ghezzo H, Cosio MG. Lymphocyte population and apoptosis in the lungs of smokers and their relation to emphysema. Eur Respir J 2001.

[32] Norma Francenia Santos-Sanchez et.al. Antioxidant compounds and their antioxidant mechanism. 2019.

[33] E R Pacht, D G Cornwell, W B Davis. Deficiency of vitamin E in the alveolar fluid of cigarette smokers. Influence on alveolar macrophage cytotoxicity. 1986.

[34] Block, E. R. 1979. Potentiation of acute paraquat toxicity by vitamin $\mathrm{E}$ deficiency. Lung. 156:195-203.

[35] Schols AM. Nutrition as a metabolic modulator in COPD. Chest. 2013.

[36] Omenn GS, Goodman GE, Thornquist MD, et al. Effects of a combination of beta carotene and vitamin A on lung cancer and cardiovascular disease. N Engl J Med. 1996.

[37] 140. Omenn GS, Goodman GE, Thornquist MD, et al. Risk factors for lung cancer and for intervention effects in CARET, the Beta-Carotene and Retinol Efficacy Trial. J Natl Cancer Inst. 1996.

[38] Goodman GE, Thornquist MD, Balmes J, et al. The Beta-Carotene and Retinol Efficacy Trial: incidence of lung cancer and cardiovascular disease mortality during 6-year follow-up after stopping beta-carotene and retinol supplements. J Natl Cancer Inst. 2004.

[39] Stey C, Steurer J, Bachmann S, Medici TC, Tramer MR. The effect of oral $n-$ acetylcysteine in chronic bronchitis: a quantitative systematic review. Eur Respir J. 2000.

[40] Decramer M, Dekhuijzen PN, Troosters T, et al. The bronchitis randomized on NAC cost-utility study (BRONCUS): hypothesis and design. Eur Respir J. 2001.

[41] Gillissen A, Jaworska M, Orth M, et al. Nacystelyn, a novel lysine salt of nacetylcysteine, to augment cellular antioxidant defence in vitro. Respir Med. 1997.

[42] Ekberg-Jansson A, Larson M, MacNee W, et al. 1999. N-isobutyrylcysteine, a donor of systemic thiols, does not reduce the exacerbation rate in chronic bronchitis.

[43] Moretti M, Bottrighi $\mathrm{P}$, Dallari R, et al. 2004. The effect of long-term treatment with erdosteine on chronic obstructive pulmonary disease: the EQUALIFE Study.

[44] Hodge S, Matthews G, Mukaro V, et al. Cigarette smoke-induced changes to alveolar macrophage phenotype and function are improved by treatment with procysteine. Am J Respir Cell Mol Biol. 2011.

[45] Butterworth M, Upshall DG, Hobbs M, et al. 1993. Elevation of cysteine and replenishment of glutathione in rat lung slices by cysteine isopropylester and other cysteine precursors. BiochemPharmacol.

[46] McCusker K, Hoidal J. 1990. Selective increase of antioxidant enzyme activity in the alveolar macrophages from cigarette smokers and smoke exposed hamsters. Am Rev Respir Dis, 141:6 78-82.

[47] Duong C, Seow HJ, Bozinovski S, Crack PJ, Anderson GP, Vlahos R. Glutathione 
peroxidase-1 protects against cigarette smoke-induced lung inflammation in mice. Am J Physiol Lung Cell Mol Physiol. 2010.

[48] Oostwoud LC, Gunasinghe P, Seow HJ, et al. Apocynin and ebselen reduce influenza a virus-induced lung inflammation in cigarette smoke-exposed mice. Sci Rep. 2016.

[49] Zhang M, Nomura A, Uchida $Y$, et al. Ebselen suppresses late airway responses and airway inflammation in guinea pigs. Free Radic. Biol Med. 2002.

[50] Haddad El B, McCluskie K, Birrell MA, et al. Differential effects of ebselen on neutrophil recruitment, chemokine, and inflammatory mediator expression in a rat model of lipopolysaccharide-induced pulmonary inflammation. J Immunol. 2002.

[51] Suzuki $Y$, Sato $T$, Sugimoto $M$, et al. Hydrogen-rich pure water prevents cigarette smoke-induced pulmonary emphysema in SMP30 knockout mice. Biochem. Biophys Res Commun. 2017; 492(1): 74-81.

[52] Lipworth BJ. 2005. Phosphodiesterase-4 inhibitors for asthma and chronic obstructive pulmonary disease. Lancet, 365:167-75.

[53] Schreck R, Albermann K, Baeuerle PA. 1992. Nuclear factor kappa B: an oxidative stress-responsive transcription factor of eukaryotic cells. Free Radic Res Commun, 17: 221-37.

[54] Rahman I, Van Schadewijk AA, Crowther A, et al. 2002. 4-Hydroxy-2nonenal, a specific lipid peroxidation product, is elevated in lungs of patients with chronic obstructive pulmonary disease. Am J Respir Crit Care Med, 166: 490-5.

[55] Di Stefano A, Caramori G, Oates T, et al. 2002. Increased expression of nuclear factor- $\mathrm{kB}$ in bronchial biopsies from smokers and patients with COPD. Eur Respir J, 20: 556-63.

[56] Jaquet V, Marcoux $\mathrm{J}$, Forest $\mathrm{E}$, et al. Nadph oxidase (NOX) isoforms are inhibited by celastrol with a dual mode of action. Br J Pharmacol. 2011; 164(2b): 507-520.

[57] Hoidal JR, Fox RB, LeMarbe PA, Perri R, Repine JE. Altered oxidative metabolic responses in vitro of alveolar macrophages from asymptomatic cigarette smokers. Am Rev Respir Dis. 1981; 123: 85-89.

[58] Hye Jung Park, Min Kwang Byun, hyung Jung Kim, Jae Yeol Kim, Yu-Il Kim, Kwang-Ha Yoo, Eun Mi Chun, Ji Ye Jung, Sanghaak Lee, Chul Min ahn. Dietary vitamin $\mathrm{C}$ intake protects against COPD: the Korea national health and nutrition examination survey in 2012.

[59] Anne H. Agler, Tobias Kurth, J. Michael Gaziano, Julie E. Buring, and Patricia A. Cassano. Randomised Vitamin E Supplementation and Risk of Chronic Lung Disease in the Women's Health Study. 2011.

[60] Ioanna G Tsiligianni, Thys van der Molen. A systematic review of the role of vitamin insufficiencies and supplementation in COPD. 2010.

[61] Kaluza, J.; Larsson, S.C.; Orsini, N.; Linden, A.; Wolk, A. Fruit and vegetable 
consumption and risk of COPD: A prospective cohort study of men. Thorax 2017.

[62] Kaluza, J.; Harris, H.R.; Linden, A.; Wolk, A. Long-term consumption of fruits and vegetables and risk of chronic obstructive pulmonary disease: A prospective cohort study of women. Int. J. Epidemiol. 2018, 47, 1897-1909.

[63] Keranis, E.; Makris, D.; Rodopoulou, P.; Martinou, H.; Papamakarios, G.; Daniil, Z.; Zintzaras, E.; Gourgoulianis, K.I. Impact of dietary shift to higherantioxidant foods in COPD: A randomised trial. Eur. Respir. J. 2010, 36, 774-780.

[64] Ochs-Balcom, H.M.; Grant, B.J.; Muti, P.; Sempos, C.T.; Freudenheim, J.L.; Browne, R.W.; McCann, S.E.; Trevisan, M.; Cassano, P.A.; Iacoviello, L.; et al. Antioxidants, oxidative stress, and pulmonary function in individuals diagnosed with asthma or COPD. Eur. J. Clin. Nutr. 2006, 60, 991-999.

[65] Andersson, I.; Gronberg, A.; Slinde, F.; Bosaeus, I.; Larsson, S. Vitamin and mineral status in elderly patients with chronic obstructive pulmonary disease. Clin. Respir. J. 2007, 1, 23-29.

[66] Esposito, K.; Giugliano, D. Whole-grain intake cools down inflammation. Am. J. Clin. Nutr. 2006, 83, 1440-1441.

[67] Massaro, M.; Scoditti, E.; Carluccio, M.A.; De Caterina, R. Basic mechanisms behind the effects of $n-3$ fatty acids on cardiovascular disease. Prostaglandins Leukot. Essent. Fatty Acids 2008.
[68] Tabak, C.; Smit, H.A.; Heederik, D.; Ocke, M.C.; Kromhout, D. Diet and chronic obstructive pulmonary disease: Independent beneficial effects of fruits, whole grains, and alcohol (the MORGEN study). Clin. Exp. Allergy 2001, 31, 747755.

[69] Miedema, I.; Feskens, E.J.; Heederik, D.; Kromhout, D. Dietary determinants of long-term incidence of chronic nonspecific lung diseases. The Zutphen Study. Am. J. Epidemiol. 1993, 138, 37-45.

[70] Li XY, Donaldson K, Rahman I, MacNee W. An investigation of the role of glutathione in increased epithelial permeability induced by cigarette smoke in vivo and in vitro. Am J Respir Crit Care Med. 1994; 149(6): 1518-1525. doi:10.1164/ajrccm.149.6.8004308

[71] Antonicelli F, Brown D, Parmentier M, et al. Regulation of LPS-mediated inflammation in vivo and in vitro by the thiol antioxidant Nacystelyn. Am J Physiol Lung Cell Mol Physiol. 2004; 286(6): L1319-L1327. doi:10.1152/ajplung.00329.2003

[72] Hodge S, Matthews G, Mukaro V, et al. Cigarette smoke-induced changes to alveolar macrophage phenotype and function are improved by treatment with procysteine. Am J Respir Cell Mol Biol. 2011; 44(5): 673-681. doi:10.1165/rcmb.2009-0459OC

[73] Martorana PA, Beume R, Lucattelli M, Wollin L, Lungarella G. Roflumilast fully prevents emphysema in mice chronically 
exposed to cigarette smoke. Am J Respir

Crit Care Med. 2005; 172(7): 848-853.

doi:10.1164/rccm.200411-1549OC

[74] Koike K, Ishigami A, Sato $\mathrm{Y}$, et al. Vitamin C prevents cigarette smokeinduced pulmonary emphysema in mice and provides pulmonary restoration. $\mathrm{Am} J$ Respir Cell Mol Biol. 2014; 50(2): 347-357. doi:10.1165/rcmb.2013-01210C

[75] Liu Y, Li A, Feng X, Sun X, Zhu X, Zhao Z. Pharmacological Investigation of the Anti-Inflammation and Anti-Oxidation Activities of Diallyl Disulfide in a Rat Emphysema Model Induced by Cigarette Smoke Extract. Nutrients. 2018; 10(1): 79. Published 2018 Jan 12. doi:10.3390/nu10010079 